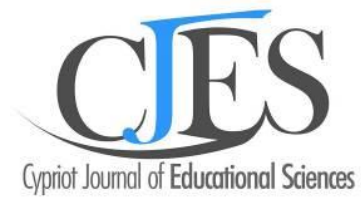

www.cjes.eu

\title{
Thematic learning during the pandemic: CIPP evaluation study
}

Pratiwi Pujiastuti ${ }^{\text {* }}$, Faculty of Education, Universitas Negeri Yogyakarta, Yogyakarta, 55281, Indonesia https://orcid.org/0000-0001-7301-5498

Herwin Herwin b ${ }^{\text {b }}$ Faculty of Education, Universitas Negeri Yogyakarta, Yogyakarta, 55281, Indonesia https://orcid.org/0000-0002-8882-5087

Fery Muhamad Firdaus c , Faculty of Education, Universitas Negeri Yogyakarta, Yogyakarta, 55281, Indonesia https://orcid.org/0000-0001-5116-8354

\section{Suggested Citation:}

Pujiastuti, P., Herwin, H., \& Firdaus, F. M. (2021). Thematic learning during the pandemic: CIPP evaluation study. Cypriot Journal of Educational Science. 16(6), 2970-3980. https://doi.org/10.18844/cjes.v16i6.6481

Received from August 18, 2021; revised from october 07, 2021; accepted from December 23, 2021.

${ }^{\circ} 2021$ Birlesik Dunya Yenilik Arastirma ve Yayincilik Merkezi. All rights reserved.

\begin{abstract}
This research is an evaluative study to evaluate thematic learning during the Covid-19 pandemic in elementary schools based on the components of context, input, process and product. The subjects of this study were principals, teachers, parents, and students. The data collection of this research was done by interview, documentation, and questionnaire. The data analysis technique used in this research is qualitative analysis. The results of the study indicate that the context in thematic learning is carried out so that students can master and develop various subject competencies in one particular theme. The thematic learning input component during the pandemic is applied on the basis of a simplified national curriculum by selecting essential competencies. Teachers, students, and parents collaborate in the success of thematic learning. The learning process is carried out synchronously and asynchronously. The learning outcomes obtained have been in the good category.
\end{abstract}

Keywords: CIPP evaluation, pandemic, thematic learning;

* ADDRESS FOR CORRESPONDENCE: Pratiwi Pujiastuti, Universitas Negeri Yogyakarta, Faculty of Education, Jalan Colombo No. 1 Karangmalang, 55281, Yogyakarta, Indonesia

E-mail address: pratiwi@uny.ac.id 
Pujiastuti, P., Herwin, H., \& Firdaus, F. M. (2021). Thematic learning during the pandemic: CIPP evaluation study. Cypriot Journal of Educational Science. 16(6), 2970-3980. https://doi.org/10.18844/cjes.v16i6.6481

\section{Introduction}

The current Covid-19 pandemic has had an impact on all fields, including education (Crawford et al., 2020; Gonzalez et al., 2020; Nicola et al., 2020; Rajhans et al., 2020). Educational activities are hampered because many schools are not allowed to carry out face-to-face learning in schools. Changes were then made to the online-based learning from home policy (Arora \& Srinivasan, 2020; Herwin et al., 2020). Educational institutions at all levels are directed to implement distance learning. This is done to prevent and handle Covid-19 in education units (Yulia, 2020). One level of education that is quite overwhelmed by the online learning system is the elementary school level (Herwin et al., 2021). This situation raises many challenges, such as difficulties in developing and implementing learning programs according to the demands of the curriculum.

One of the learning programs that must follow changes due to the pandemic is the thematic learning program in elementary schools. Thematic learning is the integration of several subjects where the existing process is packaged in the form of a theme (Chumdari et al., 2018; Rachmadani et al., 2020). This learning is generally focused on lower grades in elementary school. This program is very important in elementary school. Through thematic learning students can learn from various phenomena in everyday life so that the learning they take is expected to be meaningful (Ain \& Rahutami, 2018; MacQuarrie et al., 2015; Wardani et al., 2020).

Thematic learning is active, creative, challenging, and meaningful learning for elementary school students (Sulistyowati \& Putri, 2018). Thematic learning is an achievement of the 2013 Curriculum process. Thematic learning is an integrated learning that allows students to be active in exploring and discovering scientific concepts and principles that are meaningful and authentic. Thus, it can be concluded that thematic learning is comprehensive and integrative from various subjects at the elementary school level. Thematic learning can be integrated with character education so that the learning process is based on character education.

Based on some of these descriptions, it can be explained that thematic learning is a very important program in elementary schools. However, since the change in the education system caused by the pandemic, this program has become less controlled. Several obstacles were found in the field related to the implementation of this thematic learning. The constraints in question such as the difficulty of combining lesson topics to be adapted to distance learning. In addition, the duration of distance learning which tends to be shortened is a challenge for teachers to simplify topics and choose essential themes (Herwin et al., 2021). The facts on the ground show that there is no definite information related to the evaluation of thematic learning implementation during distance learning. During the pandemic, thematic learning tends to run based on the version of each school and this requires further evaluation to ensure the achievement of objectives.

In the implementation of a learning process, it is necessary to evaluate the implementation to know the suitability, advantages, and disadvantages of the program being implemented. This is very important, because all programs at educational institutions must be accountable (Dwi et al., 2018). Evaluation is the process of determining the value for a thing or an object based on certain references to determine certain goals. Therefore, in the implementation of thematic learning in the era of the Covid-19 pandemic at the elementary school level, evaluation is needed to find out information relating to the object being evaluated whose purpose is to provide material for decision making and determine further policy follow-up. 
Program evaluation should be carried out referring to the scientific evaluation model and considering the suitability of the program characteristics (Akinci \& Kose, 2021; Saptono et al., 2021). Answering these problems, in this study an evaluation of thematic learning programs in elementary schools was carried out. This program is evaluated for its implementation during changes to the learning system due to the pandemic. The evaluation model used is the CIPP evaluation model. Therefore, this study aims to obtain the results of the thematic learning evaluation based on the components of context, input, process, and product.

\section{Methods}

\subsection{Types of research}

This study is an evaluative study to evaluate the thematic learning program carried out during the Covid-19 pandemic in elementary schools. This evaluation uses the CIPP model, which is a model that focuses on four evaluation components, namely context, input, process, and product.

\subsection{Research subject}

This research was conducted in an elementary school in Sleman Regency, Yogyakarta, Indonesia. The subjects of this study were principals, teachers, parents, and students. The selection of subjects and locations was carried out purposively based on consideration of the distribution in each area that became the research target. In addition, the selection of subjects is also based on the mastery of information in accordance with the theme to be studied.

\subsection{Data collection technique}

Research data were collected based on the type of component to be measured. The data collection of this research was done by interview, documentation, and questionnaire. In detail, the following table 1 presents the distribution of evaluation components, data sources, and data collection carried out.

Table 1. Distribution of research data collection

\begin{tabular}{|c|c|c|c|}
\hline Evaluation components & Evaluation aspect & Data source & Data collection \\
\hline Context & Program goals & Principals, teachers & Interview \\
\hline \multirow[t]{4}{*}{ Input } & Curriculum & Principals, teachers & Interview \\
\hline & Teacher & Principals, teachers & Interview \\
\hline & Student & Principals, Teachers & Interview \\
\hline & Facility & $\begin{array}{l}\text { Principals, teachers, } \\
\text { students, parents }\end{array}$ & $\begin{array}{l}\text { Interview, } \\
\text { documentation } \\
\text { questionnaire }\end{array}$ \\
\hline Process & Learning process & $\begin{array}{l}\text { Principals, teachers, } \\
\text { students, parents }\end{array}$ & $\begin{array}{l}\text { Interview, } \\
\text { documentation, } \\
\text { questionnaire }\end{array}$ \\
\hline Product & Learning outcomes & $\begin{array}{l}\text { Principals, teachers, } \\
\text { students, parents }\end{array}$ & $\begin{array}{l}\text { Interview, } \\
\text { documentation }\end{array}$ \\
\hline
\end{tabular}

\subsection{Data analysis technique}

The data analysis technique used in this research is qualitative analysis. The data obtained from the field is then continued in the process of data condensation and data verification to obtain conclusions. In addition, to ensure the validity of the data obtained, data triangulation is carried out. The type of 
triangulation carried out is source triangulation. In addition, time triangulation is also carried out through an extension of time to strengthen the accuracy of the data obtained for the purpose of drawing conclusions.

\section{Results and discussion}

This research was conducted by combining various information from data sources such as principals, teachers, students, and parents. This is expected to obtain more detailed information related to the implementation of the learning program that is the target of the evaluation. The results of this study are described based on the research focus, namely the evaluation of thematic learning in elementary schools during the Covid 19 pandemic. Based on the evaluation model used, the results of this study are described based on the four main components of the evaluation, namely context, input, process, and product. The results related to the four components can be explained as follows.

\subsection{Context of learning program}

The context referred to in this study is the purpose of the thematic learning program implemented in schools. This is the first focus because it is related to the basis of this program being implemented for elementary school students. The results of the study indicate that the expected goals in the implementation of thematic learning are generally centred on the interests of student development. This thematic learning is carried out so that students can focus on certain themes or topics. This is done by learning knowledge and developing various subject competencies in the same theme so that understanding of the subject matter is more profound and memorable.

In addition, through thematic learning, students are expected to develop better language competence by linking various other subjects with students' personal experiences. Teachers can save time, because the subjects that are presented in an integrated manner can be prepared at once and given in 2 or 3 meetings or even more and or enrichment.

Another goal in organizing this program is that students are expected to be more passionate about learning because they can communicate in learning, such as: telling stories, asking questions, writing while learning other subjects. Students are expected to feel the benefits and meaning of learning more because the material presented is in the context of a clear theme. In addition, the most important thing is that through thematic learning, students' character and morals can be grown and developed by raising several character values according to the situation and conditions.

The findings of this study are relevant to several studies that show thematic learning objectives are implemented in elementary schools (Istiningsih, 2017; Winarni et al., 2018). Thematic learning is presented by uniting various learning contents so that they become a single unit in the theme. Thematic learning is implemented as a medium to improve students' critical thinking skills. Students' divergent thinking skills are expected to develop through this thematic learning (Fauziah et al., 2020; Walid et al., 2019). In addition, this learning is also expected to increase students' creativity and activeness during the learning process, so that it has an impact on maximum learning outcomes (Elisa et al., 2019).

\subsection{Input of learning program}

The thematic learning program inputs discussed in this study include the implementation of the learning curriculum, teacher activities in learning activities, student activities during lessons and available learning facilities. Findings on the curriculum aspect show that during the pandemic, the implementation of the curriculum in primary schools was found in 3 ways. The first way is for teachers 
to continue using the 2013 Curriculum as usual before the pandemic but with adjustments to essential competencies. The second way is for teachers to use an emergency curriculum that has been directed by the ministry of education after the pandemic status began. The third way is for teachers to use an independent curriculum that has been agreed upon in schools by adjusting to the pandemic emergency conditions. Although three ways of implementation were found, the core curriculum applied still refers to the existing national curriculum, it's just that the implementation in the field adapts to the unique problems and obstacles found in each region.

Changes in the learning system due to the pandemic have allowed teachers and schools to adjust the curriculum implemented in schools (Herwin et al., 2021). Giving the opportunity to adapt this curriculum is a form of opportunity for schools and educational institutions to choose the best alternative in carrying out the learning process (Abidah et al., 2020). Generally, curriculum adjustments are always followed by the integration of technology in achieving the desired learning objectives in the curriculum (Luthra \& Mackenzie, 2020). In addition, in adjusting and simplifying the curriculum, teachers also need to consider learning time (Goodson et al., 2015). During the pandemic, study time for students and teachers tends to be shortened compared to usual. This is a consideration in the adjustment and simplification of the essential competencies of the curriculum.

Another thing that becomes an evaluation aspect in the evaluation of this input component is the readiness and quality of teachers. The findings of this study indicate that to improve the quality of input from teachers, schools make efforts to improve teacher skills in integrating technology in their learning activities. This is done by training in the use of LMS, developing skills in conducting online learning, as well as training for teachers to develop a mobile-based learning assessment model. This is done to provide reinforcement for teacher input to be able to adapt to changes in the pandemic situation. This is very important because the teacher is one of the resources that is the main key in learning activities. The quality of education and the quality of learning is highly dependent on the quality of teachers (Malkab et al., 2015; Tjabolo \& Herwin, 2020).

Besides the teacher, the presence of students is also an input for this thematic learning. Students are involved as learning objects and become the main target in learning activities. The success of the learning process, one of which is based on student achievement of the competencies that must be achieved. During the pandemic, student learning activities also experienced significant changes. Their activities are carried out from home and many also get help from their parents. This means that in the aspect of student activities, their learning activities are also influenced by the help and assistance of parents at home. Basically, this is a positive thing because parents also have an important role in the success of their children's learning (Đurišić \& Bunijevac, 2017). In addition, the presence of parents in learning at home also provides emotional support to strengthen students' readiness to learn (Bhamani et al., 2020; Wang et al., 2020). Parents must be present in overcoming the limitations felt by students in learning (Dai \& Lin, 2020; Xia, 2020; Xie \& Yang, 2020).

Another aspect that is no less important in evaluating the input component is learning facilities. The findings of this study indicate that during the pandemic, learning activity facilities remain a concern for the school and cooperate with the role of parents at home. The findings of this study indicate that some learning facilities are prepared by schools such as material modules, LMS, internet quota assistance and teacher guidance services. Furthermore, other facilities are provided by parents at home such as smart phones, computers, laptops, and other supporting facilities. In general, the findings on the components of learning facilities gave satisfactory results. Students can feel the facilities provided for learning activities. This is very important, because learning facilities are one of the factors that generate students' 
motivation to learn (Alfiansyah, 2019). In addition to facilities from schools, the availability of learning facilities at home is a form of the presence of parents for their attention to their children's education (Murray et al., 2015).

\subsection{Process of learning program}

The restrictions due to the pandemic make the thematic learning process must be carried out remotely. The learning process is carried out from the homes of each student and teacher. In this process the teacher utilizes technology in the learning process. Learning activities take place in two types, namely synchronous and asynchronous. This is done by the teacher regularly and thoughtfully to convey learning competencies to students. Synchronous activities are carried out through online meetings to convey the essential competencies that have been determined. Meanwhile, other supporting competencies are carried out asynchronously through structured assignments. These two things are always carried out proportionally based on the distribution of competencies and themes to be conveyed to students.

The results of the evaluation on this component are in line with the findings which state that the combination of synchronous and asynchronous learning activities is a form of teacher innovation to create variety and prevent student boredom when participating in learning activities (Herwin et al., 2021). Synchronous activities such as Zoom meetings are needed to convey material that is difficult to do through asynchronous techniques (Bawanti \& Arifani, 2021; Nadezhda, 2020). Furthermore, the supportive asynchronous method is also important because it is supported by constructivist theory that is student-centred and emphasizes the importance of independent learning in students (Shahabadi \& Uplane, 2015). In addition, through asynchronous activities students can use more flexible time to study certain themes according to their needs (Malik et al., 2017).

Teachers are required to plan, implement processes, and evaluate learning effectively and efficiently (Wuryandani \& Herwin, 2021). Teachers have a responsibility to integrate technology in learning activities so that goals can be achieved (Senen et al., 2021). In general, in the case of thematic learning in this study, the teacher has carried out the learning process through several adjustments to the pandemic situation. Of course, some of the obstacles that are often felt are internet network problems, uneven facilities due to the diversity of abilities of parents. However, following up on these limitations, of course, the teacher continues to evaluate to carry out a follow-up plan.

\subsection{Product of learning program}

The product components in the results of this evaluation are student learning outcomes when participating in thematic learning during the pandemic. The findings of this evaluation are obtained from the learning outcomes document which is a record of student learning progress and achievements. The document was obtained from the teacher. The results showed that the average student learning outcomes in thematic learning during the pandemic were in the good category. Some students have been able to complete the learning materials with very good achievements. Only a small percentage have low achievement. The interesting thing found in this component is that although students have achieved good learning outcomes in documents, they feel they have not fully mastered the learning competencies well. Some of the students also felt dissatisfied with thematic learning with the distance learning system. But they also realize that this is the best option during a pandemic. 
Assignments on distance learning often make students feel anxious and dissatisfied (Cui et al., 2021; Zhao et al., 2020). In addition, the learning system carried out from home also makes parents stressed about the learning process that must be passed by their children (Martins-Filho et al., 2020). Therefore, conflicts between children and parents often occur in this learning process (Toney et al., 2003). This is difficult to avoid because the role of parents in their children's education is very much needed (Sujarwo et al., 2021). In terms of learning products, online learning can have advantages related to learning efficiency (Bientzle et al., 2019; Meinert et al., 2019). On the other hand, online learning can be a threat to the low effectiveness of learning outcomes (Cook et al., 2013). Therefore, teachers must anticipate weaknesses that pose a threat and maximize the advantages of thematic learning conducted online during the pandemic. It is very important that learning products can be achieved effectively and efficiently.

\section{Conclusion}

This study concludes that the context in thematic learning is carried out so that students can learn by focusing on a particular theme or topic, can master and develop various subject competencies in the same theme so that understanding of the subject matter is more profound and memorable. The thematic learning input component during the pandemic is applied based on a simplified national curriculum by selecting essential topics and competencies. Teachers are equipped with technology integration skills in learning and students learn from home through parental assistance. Learning facilities are prepared by schools such as LMS, internet quota assistance, modules, and other supporting materials. Facilities at home are tailored to the abilities of each student's parents. The learning process is carried out remotely with two alternating learning activities, namely synchronous and asynchronous activities. Learning products in the form of student learning outcomes have been in the good category, but the level of student satisfaction is still low on the implementation of thematic learning with the distance system.

This study recommends the development of resources to policy makers to strengthen the input and process components. This is done by providing training and mentoring for teachers to improve their ability to integrate technology in their learning activities according to the characteristics and abilities of students in learning. Online learning facilities need to get further attention in order to facilitate the process of learning activities. In addition, it is also necessary to strengthen the pedagogical competence of teachers who have relevance to distance learning. This study also recommends further studies related to the level of satisfaction of students and parents in participating in thematic learning during the pandemic.

\section{Acknowledgements}

We would like to express our deepest gratitude to the Chancellor of Universitas Negeri Yogyakarta who has been motivating us to complete this research. Thank you to the research respondents who have agreed to cooperate in the implementation of this research. 


\section{References}

Abidah, A., Hidaayatullaah, H. N., Simamora, R. M., Fehabutar, D., \& Mutakinati, L. (2020). The impact of Covid-19 to Indonesian Education and its relation to the philosophy of "Merdeka Belajar." Studies in Philosophy of Science and Education, 1(1), 38-49. https://doi.org/10.46627/sipose.v1i1.9

Ain, N., \& Rahutami, R. (2018). Theme network in thematic learning in elementary school. Journal of Physics: Conference Series, 1013, 012065. https://doi.org/10.1088/1742-6596/1013/1/012065

Akinci, M., \& Kose, E. (2021). Research trends of program evaluation studies conducted between $2010-$ 2019 in Turkey. Cukurova University Faculty of Education Journal, 50(1), 77-120. https://doi.org/10.14812/cufej.688142

Alfiansyah, H. R. (2019). The role of parental involvement towards the students' learning motivation. Lentera Pendidikan: Jurnal Ilmu Tarbiyah Dan Keguruan, 22(2), 276-283. https://doi.org/10.24252/lp.2019v22n2i9

Arora, A. K., \& Srinivasan, R. (2020). Impact of Pandemic Covid-19 on the Teaching-Learning Process : A Study of Higher Education Teachers. Prabandhan: Indian Journal of Management, 13(4), 43-56. https://doi.org/10.17010/pijom/2020/v13i4/151825

Bawanti, P. K. D., \& Arifani, Y. (2021). Students' perceptions of using Zoom application on mobile phone in improving speaking skills during online learning at Ban Loeiwangsai School, Loei Province, Thailand. Journal of English Teaching, Literature, and Applied Linguistics, 5(1), 54-61. https://doi.org/10.30587/jetlal.v5i1.2212

Bhamani, S., Makhdoom, A. Z., Bharuchi, V., Ali, N., Kaleem, S., \& Ahmed, D. (2020). Home learning in times of Covid: Experiences of parents. Journal of Education and Educational Development, 7(1), 9. https://doi.org/10.22555/joeed.v7i1.3260

Bientzle, M., Hircin, E., Kimmerle, J., Knipfer, C., Smeets, R., Gaudin, R., \& Holtz, P. (2019). Association of online learning behavior and learning outcomes for medical students: Large-scale usage data analysis. JMIR Medical Education, 5(2), e13529. https://doi.org/10.2196/13529

Chumdari, C., Sri Anitah, S. A., Budiyono, B., \& Nunuk Suryani, N. (2018). Implementation of thematic instructional model in elementary school. International Journal of Educational Research Review, 3(4), 23-31. https://doi.org/10.24331/ijere.424241

Cook, D. A., Sorensen, K. J., Hersh, W., Berger, R. A., \& Wilkinson, J. M. (2013). Features of effective medical knowledge resources to support point of care learning: A focus group study. PLOS ONE, 8(11), e80318. https://doi.org/10.1371/journal.pone.0080318

Crawford, J., Butler-Henderson, K., Rudolph, J., Malkawi, B., Glowatz, M., Burton, R., Magni, P., \& Lam, S. (2020). Covid-19: 20 countries' higher education intra-period digital pedagogy responses. Journal of Applied Learning \& Teaching, 3(1), 1-20. https://doi.org/10.37074/jalt.2020.3.1.7

Cui, S., Zhang, C., Wang, S., Zhang, X., Wang, L., Zhang, L., Yuan, Q., Huang, C., Cheng, F., Zhang, K., \& Zhou, X. (2021). Experiences and attitudes of elementary school students and their parents toward online learning in China during the Covid-19 Pandemic: Questionnaire study. Journal of Medical Internet Research, 23(5), e24496. https://doi.org/10.2196/24496

Dai, D., \& Lin, G. (2020). Online home study plan for postponed 2020 spring semester during the Covid- 
19 epidemic: A case study of tangquan middle school in Nanjing, Jiangsu Province, China. SSRN Electronic Journal, 4(2), 543-547. https://doi.org/10.2139/ssrn.3555539

Đurišić, M., \& Bunijevac, M. (2017). Parental involvement as a important factor for successful education. Center for Educational Policy Studies Journal, 7(3), 137-153. https://www.cepsj.si/index.php/cepsj/article/view/291

Dwi, Y. R., Haryono, H., \& Florentinus, T. S. (2018). The evaluation of the CIPP Model in the implementation of character education at junior high school. Innovative Journal of Curriculum and Educational Technology, 7(2), 65-77. https://doi.org/10.15294/ijcet.v7i2.28391

Elisa, L., Hadiyanto, H., \& Fitria, Y. (2019). Application of learning model auditory, intellectually, repetition (air) to increase student activity and learning outcomes in 2013 curriculum integrated thematic learning in class IV SDN 06 Hand of Padang. International Journal of Educational Dynamics, 1(2), 156-162. https://doi.org/10.24036/ijeds.v1i2.126

Fauziah, M., Marmoah, S., Murwaningsih, T., \& Saddhono, K. (2020). Profile of divergent thinking ability of elementary school student in thematic learning. ilköğretim Online, 19(2), 624-640. https://doi.org/10.17051/ilkonline.2020.693109

Gonzalez, T., de la Rubia, M. A., Hincz, K. P., Comas-Lopez, M., Subirats, L., Fort, S., \& Sacha, G. M. (2020). Influence of Covid-19 confinement on students' performance in higher education. PLOS ONE, 15(10), 1-23. https://doi.org/10.1371/journal.pone.0239490

Goodson, C. E., Miertschin, S. L., \& Stewart, B. L. (2015). Time management skills and student performance in online courses. The ASEE Computers in Education (COED) Journal, 7(2), 37-48. https://doi.org/10.18260/p.24921

Herwin, H., Hastomo, A., Saptono, B., Ardiansyah, A. R., \& Wibowo, S. E. (2021). How elementary school teachers organized online learning during the Covid-19 Pandemic? World Journal on Educational Technology: Current Issues, 13(3), 437-449. https://doi.org/10.18844/wjet.v13i3.5952

Herwin, H., Jabar, C. S. A., Senen, A., \& Wuryandani, W. (2020). The evaluation of learning services during the Covid-19 Pandemic. Universal Journal of Educational Research, 8(11), 5926-5933. https://doi.org/10.13189/ujer.2020.082227

Istiningsih, I. (2017). Empowerment of teachers in implementing thematic learning method. Journal of Education and Practice, 8(3), 64-70. http://digilib.uin-suka.ac.id/id/eprint/25327

Luthra, P., \& Mackenzie, S. (2020). 4 ways Covid-19 could change how we educate future generations. World Economic Forum. https://www.weforum.org/agenda/2020/03/4-ways-covid-19-educationfuture-generations/

MacQuarrie, S., Nugent, C., \& Warden, C. (2015). Learning with nature and learning from others: nature as setting and resource for early childhood education. Journal of Adventure Education and Outdoor Learning, 15(1), 1-23. https://doi.org/10.1080/14729679.2013.841095

Malik, M., Fatima, G., Hussain, A., \& Sarwar, A. (2017). E-Learning: Students' perspectives about asynchronous and synchronous resources at higher education level. Bulletin of Education and Research, 39(2), 183-195.

Malkab, M., Nawawi, J., Mahmud, A., \& Sujiono, E. H. (2015). The implementer disposition of teacher certification policy in Indonesia. International Education Studies, 8(5). 
Pujiastuti, P., Herwin, H., \& Firdaus, F. M. (2021). Thematic learning during the pandemic: CIPP evaluation study. Cypriot Journal of Educational Science. 16(6), 2970-3980. https://doi.org/10.18844/cjes.v16i6.6481

https://doi.org/10.5539/ies.v8n5p54

Martins-Filho, P. R., Damascena, N. P., Lage, R. C., \& Sposato, K. B. (2020). Decrease in child abuse notifications during Covid-19 outbreak: A reason for worry or celebration? Journal of Paediatrics and Child Health, 56(12), 1980-1981. https://doi.org/10.1111/jpc.15213

Meinert, E., Alturkistani, A., Foley, K. A., Brindley, D., \& Car, J. (2019). Examining cost measurements in production and delivery of three case studies using e-learning for applied health sciences: Crosscase synthesis. Journal of Medical Internet Research, 21(6), e13574. https://doi.org/10.2196/13574

Murray, E., McFarland-Piazza, L., \& Harrison, L. J. (2015). Changing patterns of parent-teacher communication and parent involvement from preschool to school. Early Child Development and Care, 185(7), 1031-1052. https://doi.org/10.1080/03004430.2014.975223

Nadezhda, G. (2020). Zoom technology as an effective tool for distance learning in teaching English to medical students. Pedagogical Sciences, 6(5), 457-460. https://doi.org/10.33619/24142948/53/61

Nicola, M., Alsafi, Z., Sohrabi, C., Kerwan, A., Al-Jabir, A., losifidis, C., Agha, M., \& Agha, R. (2020). The socio-economic implications of the coronavirus pandemic (Covid-19): A review. International Journal of Surgery, 78, 185-193. https://doi.org/10.1016/j.ijsu.2020.04.018

Rachmadani, F., Murtiningsih, S., \& Maharani, S. D. (2020). The application of model thematic learning to building basic capability for children with special needs. Jurnal Pendidikan: Teori Dan Praktik, 5(1), 8-17. https://doi.org/10.26740/jp.v5n1.p\%25p

Rajhans, V., Memon, U., Patil, V., \& Goyal, A. (2020). Impact of Covid-19 on academic activities and way forward in Indian Optometry. Journal of Optometry, 13(4), 216-226. https://doi.org/10.1016/j.optom.2020.06.002

Saptono, B., Herwin, H., \& Firmansyah, F. (2021). Web-based evaluation for teacher professional program: Design and development studies. World Journal on Educational Technology: Current Issues, 13(4), 672-683. https://doi.org/10.18844/wjet.v13i4.6253

Senen, A., Sari, Y. P., Herwin, H., Rasimin, R., \& Dahalan, S. C. (2021). The use of photo comics media: Changing reading interest and learning outcomes in elementary social studies subjects. Cypriot Journal of Educational Sciences, 16(5), 2300-2312. https://doi.org/10.18844/cjes.v16i5.6337

Shahabadi, M. M., \& Uplane, M. (2015). Synchronous and asynchronous e-learning styles and academic performance of e-learners. Procedia - Social and Behavioral Sciences, 176, 129-138. https://doi.org/10.1016/j.sbspro.2015.01.453

Sujarwo, S., Kusumawardani, E., Prasetyo, I., \& Herwin, H. (2021). Parent involvement in adolescents' education: A case study of partnership models. Cypriot Journal of Educational Sciences, 16(4), 1563-1581. https://doi.org/10.18844/cjes.v16i4.6013

Sulistyowati, P., \& Putri, N. M. (2018). Development of Contextual Teaching and Learning (CTL) based module teaching materials Class IV Theme 3 Sub-theme 1. Jurnal Pendidikan (Teori Dan Praktik), 3(1), 1-6. https://doi.org/10.26740/jp.v3n1.p1-6

Tjabolo, S. A., \& Herwin, H. (2020). The influence of teacher certification on the performance of elementary school teachers in Gorontalo Province, Indonesia. International Journal of Instruction, 
13(4), 347-360. https://doi.org/10.29333/iji.2020.13422a

Toney, L. P., Kelley, M. Lou, \& Lanclos, N. F. (2003). Self and parental monitoring of homework in adolescents: Comparative effects on parents' perceptions of homework behavior problems. Child \& Family Behavior Therapy, 25(1), 35-51. https://doi.org/10.1300/J019v25n01_03

Walid, M., Musthofa Malik, A., Arifuddin, A., Uyun, F., \& Busro, B. (2019). Development of advanced micro devices media to enhance student concept understanding in thematic learning. Journal of Physics: Conference Series, 1175, 012176. https://doi.org/10.1088/1742-6596/1175/1/012176

Wang, G., Zhang, Y., Zhao, J., Zhang, J., \& Jiang, F. (2020). Mitigate the effects of home confinement on children during the Covid-19 outbreak. The Lancet, 395(10228), 945-947. https://doi.org/10.1016/S0140-6736(20)30547-X

Wardani, N. F. K., Sunardi, \& Suharno. (2020). Thematic learning in elementary school: Problems and possibilities. Proceedings of the 3rd International Conference on Learning Innovation and Quality Education (ICLIQE 2019), 791-800. https://doi.org/10.2991/assehr.k.200129.099

Winarni, E. W., Purwandari, E. P., Lusa, H., \& Dadi, S. (2018). The impact of thematic learning integrated ICT in Tabot Bengkulu as cultural ceremony toward social interaction knowledge in elementary school. Asian Journal of Education and Training, 4(2), 70-74. https://doi.org/10.20448/journal.522.2018.42.70.74

Wuryandani, W., \& Herwin, H. (2021). The effect of the think-pair-share model on learning outcomes of Civics in elementary school students. Cypriot Journal of Educational Sciences, 16(2), 627-640. https://doi.org/10.18844/cjes.v16i2.5640

Xia, J. (2020). Practical exploration of school-family cooperative education during the Covid-19 epidemic: A case study of Zhenjiang Experimental School in Jiangsu Province, China. SSRN Electronic Journal, 4(2), 521-528. https://doi.org/10.2139/ssrn.3555523

Xie, Z., \& Yang, J. (2020). Autonomous learning of elementary students at home during the Covid-19 epidemic: A case study of the second elementary school in Daxie, Ningbo, Zhejiang Province, China. SSRN Electronic Journal, 4(2), 535-541. https://doi.org/10.2139/ssrn.3555537

Yulia, H. (2020). Online learning to prevent the spread of Pandemic Corona Virus in Indonesia. ETERNAL (English Teaching Journal), 11(1), 48-56. https://doi.org/10.26877/eternal.v11i1.6068

Zhao, Y., Guo, Y., Xiao, Y., Zhu, R., Sun, W., Huang, W., Liang, D., Tang, L., Zhang, F., Zhu, D., \& Wu, J.-L. (2020). The effects of online homeschooling on children, parents, and teachers of Grades 1-9 during the Covid-19 Pandemic. Medical Science Monitor, 26, e925591-1. https://doi.org/10.12659/MSM.925591 